\title{
МЕТАЛЕВІ КОНСТРУКЦІї В СУЧАСНОМУ БУДІВНИЦТВІ
}

\section{METAL STRUCTURES IN MODERN CONSTRUCTION}

Талах Л.О., к.т.н., доц., Шимчук О.П., к.т.н., доц., Процюк В.О., к.т.н., ст. викладач, Семерей А.С., студент, Панасюк Я.І., к.т.н., доц. (Луцький національний технічний університет, м. Луцьк)

Talakh L.O., Ph.D. in Engineering, Associate Professor, Shymchuk O.P., Ph.D. in Engineering, Associate Professor, Protsiuk V.O., Ph.D. in Engineering, senior lecturer, Semerei A.S., student, Panasuk Y.I., Ph.D. in Engineering, Associate Professor (Lutsk National Technical University, Lutsk)

Виконано аналіз щуодо використання металевих конструкиій в сучасному будівництві та розглянуті можливості удосконалення їх з метою широкого використання не лише у промисловому, циивільному, комерційному, а і житловому будівництві, а також вивчено проблеми у зазначеній галузі та шляхи їх усунення. (Стаття оглядова)

An analysis of the use of metal structures in modern construction and considered the possibility of improving them for widespread use not only in industrial, civil, commercial, but also residential construction.

High performance characteristics, high strength and homogeneity of the metal structure explain its demand in the field of construction.

The steel framework allows to increase considerably functionality of the building and to reduce terms of its construction. In comparison with various modern materials, each steel structure has key and undeniable advantages - a high degree of factory readiness, full maintainability and reusability.

Rolled steel is increasingly used, and its range, as well as the physical and chemical properties of alloys are constantly improving. At the same time, due to their versatility in processing, strength, maintainability, reliability in operation and industry of steels, their application solves numerous problems of residential, commercial and industrial construction.

Alloys with new alloying components allow: to create light steel and thin-walled structures with the increased bearing capacity; to conduct cheap construction of small and high-rise buildings and structures; to improve the architectural appearance of buildings; ensure high rates of production.

Metal is becoming a formative factor in architecture, especially in new types of buildings - modern exhibition and sports complexes, railway stations, shopping malls, stadiums, not to mention the transport, industrial and civil construction. Metal is a specific means of architectural development of space.

Given the ratio of strength and density, steel is considered a lightweight building material. In comparison with a tree this factor at it is lower twice, in comparison with 
concrete - in $8 \ldots 10$ times and in comparison with a brick - in 18 ... 20 times. Accordingly, buildings and structures with a steel frame can be erected on pile, tile and strip foundations of lightweight construction. (Review article)

Ключові слова: металеві конструкиії, міиність, сталь, ивидкомонтовані конструкиї̈, сталевий каркас.

Keywords: metal structures, strength, steel, prefabricated structures, steel frame.

Вступ. Розвиток сталевого будівництва в Україні неможливий без усвідомлення важливості в аналізі використання сталевих конструкцій у розвинутих країнах світу та втіленні найкращих ідей в українське будівництво. Науково-технічний прогрес в цьому напряму потребує пошуку нових високоміцних сталей, нових форм сталевих конструкцій. Реалізувати ці ідеї можливо лише шляхом модернізації вже існуючих виробництв і їх нарощуванні, а також у будівництві нових заводів 3 автоматизованого виготовлення різного роду конструкцій за світовими стандартами.

Фізико-механічні властивості сталей, з яких виготовляються металеві конструкції, високі експлуатаційні характеристики надали можливість їх широкого використання у будівництві. Висока міцність, легкість та надійність дозволили зводити високі та великопрогонові будівлі.

Аналіз досліджень. Використання сталевих конструкцій у будівельній галузі в Україні займає не велику частку в порівнянні 3 іншими країнами. «Поки що частка сталевого будівництва не перевищує 15\%. Будівельний ринок в Україні невеликий - 2,2\% у структурі ВВП. В Європі середній показник становить 6\%, а в Туреччині - $10 \%$ ВВП» [1].

Сьогодні велика затребуваність житла, сучасних промислових, інфраструктурних, оздоровчих та ін. об'єктів. Для реалізації попиту необхідні великі фінанси, яких, на жаль, в Україні немає.

При правильному підході у плануванні та інвестуванні у будівельну галузь все можливо змінити на краще, адже велика кількість підприємств, в тому числі і малий та середній бізнес, прямо чи опосередковано, залучені до будівельного сектору. Розвиток будівництва надає можливості збільшення робочих місць і інвестування в галузь не лише великих корпорацій, але й населення.

Використовують металеві конструкції в Україні в 2 - 2,5 рази менше, ніж у розвинутих країнах Європи. Найбільше вони використовуються у Великобританії. В основному застосовуються сталеві конструкції у комерційному будівництві. Будівництво житла в цьому питанні значно уповільнено. В Україні цей відсоток близько одиниці, тоді як в Японії, США і Швеції-10-15\% [2]. 
Постановка мети і задачі досліджень. Метою роботи є дослідити перспективність використання металевих конструкцій у сучасному будівництві промислових, цивільних і житлових будівель.

Основними задачами дослідження $\epsilon$ визначення основних характеристик сталі, як основного матеріалу для проектування металевих конструкцій, переваг та недоліків, знаходження шляхів для оптимізації сталевого будівництва, вивчення проблем у зазначеній галузі та шляхи їх усунення.

Виклад основного матеріалу. Металеві конструкції, які знайшли своє використання в будівельній галузі мають широкий спектр відмінності - висота, прогін, форма та матеріал, з якого вони виготовлені. Левова частина їх виготовляється на заводах.

Для полегшення металевих конструкцій, а разом з тим, зменшення навантаження на фундаменти, широко застосовуються бісталеві конструкції, решітчасті та конструкції або їх елементи, які виготовлені 3 високоміцних і легованих сталей. Саме введення в каркас будівлі таких конструкцій надало їм перевагу над масивними залізобетонними, які потребували встановлення опалубки, часу на тужавіння та інше.

Затребуваність у технології будівництва 3 використанням металоконструкцій сьогодні $є$ дуже велика, так як строки будівництва скорочуються в кілька разів.

Металевий каркас - це остов будівлі, який забезпечує ії міцність, стійкість і жорсткість. Правильний вибір конструкцій для сталевого каркасу забезпечує надійність споруди загалом. Саме тому при проектуванні велике значення має створення моделі будівлі, яка надає можливість аналізувати роботу кожної конструкції в реальних умовах. У всіх розтягнутих елементах значної довжини рекомендується встановлення шпренгелів для зменшення їх провисання, а стиснуті стержні проектувати короткими і якщо необхідно, то зі сталей підвищеної міцності.

При проектуванні металевих конструкцій матеріал вибирається, виходячи 3 особливостей будівель, географічного положення, умов виготовлення, монтажу та експлуатації [3].

«Вибір сталі залежить від наступних параметрів, які впливають на роботу матеріалу: температури середовища; характеру навантаження; виду напруженого стану; способу з'єднання елементів; товщини прокату. Найчастіше використовується гарячекатана вуглецева сталь звичайної і підвищеної якості, а в деяких випадках низьколегована сталь підвищеної міцності. Частка листового металу в готовому виробі може досягати до $30 \ldots 60 \%$, а буває і $90 \ldots 95 \% »[4]$.

Кожна металева конструкція складається 3 окремих елементів, з'єднаних між собою в одне ціле. Форма конструкції залежить від типу споруди і іiї призначення, враховуючи не лише показники за надійністю, але й за стильністю та архітектурною виразністю. Для цього 
використовують різноманітні профілі. Серед затребуваних значне місце мають C-, U-, Z-, П - подібні профілі, закриті коробчасті та трубчасті профілі. Всі ці вище зазначені профілі надають можливість проектували легкі металеві конструкції (ЛМК) значної довжини, які не поступаються своїми властивостями традиційним [4].

Сталевий каркас дозволяє значно підвищити функціональність будівлі і скоротити терміни ï будівництва. Сучасні сталеві конструкції мають ключові переваги - висока ступінь заводської готовності, повна ремонтопридатність і можливість вторинного використання.

Провідні будівельні компанії всього світу вже відмовилися від традиційного виду будівництва, віддавши перевагу швидкомонтованим будівлям (ШИБ).
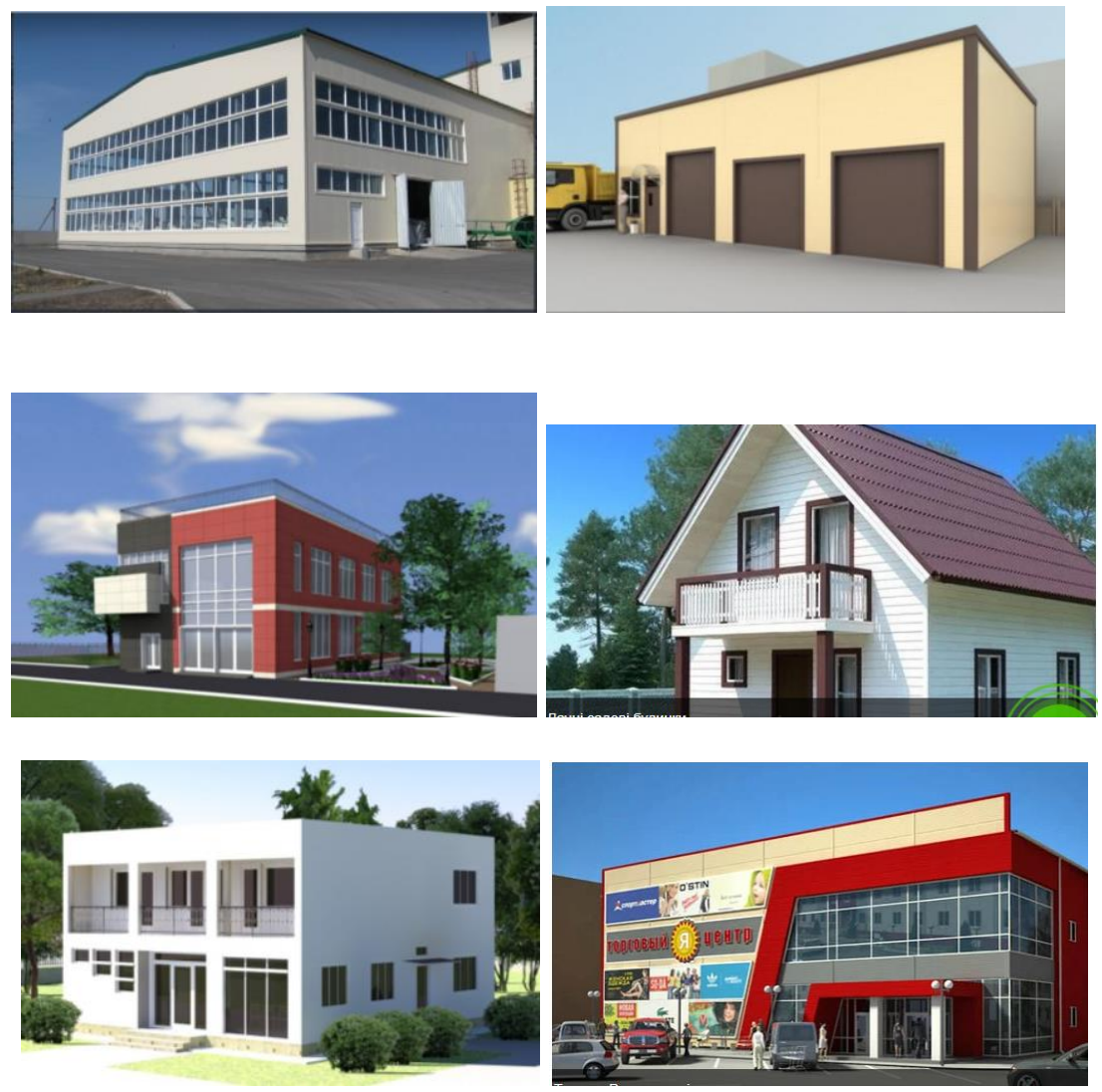

Рис.1. Приклади проєктів з використанням швидкомонтованих конструкцій у промисловому, комерційному та цивільному будівництві 
Технологія такого будівництва дозволяє економити кошти на матеріалах і трудові ресурси, а також будувати швидко та якісно у будьяку пору року. За цією технологією вже побудовано багато об'єктів сільськогосподарського призначення, великих супермаркетів, логістичних центрів та інше.

Легкість і просте рішення каркасу та огороджувальних елементів будівлі, різновиди утеплювачів у сендвіч-панелях розширює можливість будувати у різних кліматичних, в тому числі, важкодоступних регіонах країни і має великі перспективи.

3 введенням в дію у 2015 році ДБН В.2.6-198:2014, а у 2016 році 3 прийняттям угоди про вільну торгівлю між Україною та ЄС, значно розширилася номенклатура металевих конструкцій, сортаменту, різних марок сталі для їх виготовлення та ін. на ринку нашої країни [3]. Це надало можливість мати доступ до якісної імпортної продукції і підвищити якість своєї української. 3 кожним роком попит на будівництво будівель 3 використанням металевих конструкцій зростає, як окремо взятих елементів, так і каркасу в цілому. Разом з цим, такий стан речей надав можливість будувати будівлі та споруди для різного призначення промислові, цивільні, житлові. Щодо останнього, то необхідно відміти, що будівництво житлових будинків зі сталевих конструкцій в Україні мало розвинуто, але збільшення будівництва саме в цьому напрямі може значно прискорити вирішення житла для молодих сімей, сімей 3 низьким рівнем достатку i, що дуже важливо для переселенців окупованого Донбасу. Таке житло будується в короткі терміни, $є$ порівняно дешевим, комфортним і теплим.

«Пластичність металу і його універсальність в обробці знімають будьякі обмеження i забезпечують широкий простір для проектування житлових будинків, спортивних споруд і суспільно корисних будівель» [5].

Метал стає формотворчим фактором архітектури, особливо в нових типах будинків - сучасних виставкових i спортивних комплексах, вокзалах, торгових центрах, стадіонах, не говорячи вже про транспортне, промислове та цивільне будівництво. Метал виступає специфічним засобом архітектурного освоєння простору.

«3 огляду на співвідношення міцності і щільності, сталь вважається легким будівельним матеріалом. У порівнянні $з$ деревом цей коефіцієнт у неї нижче в два рази, в порівнянні з бетоном - в $8 \ldots 10$ разів і в порівнянні 3 цеглою - в 18 ... 20 разів. Відповідно, будівлі та споруди зі сталевих каркасом можуть зводитися на пальових, плиткових i стрічкових фундаментах полегшеної конструкції» [5].

Використовуючи металоконструкції і сталевий каркас, архітектори зможуть реалізувати індивідуальні, відомі всьому світі свої проєкти, створюючи неповторні архітектурні ансамблі, поєднуючи конструктивні форми з гармонійністю, виразністю та унікальністю (рис.2). 


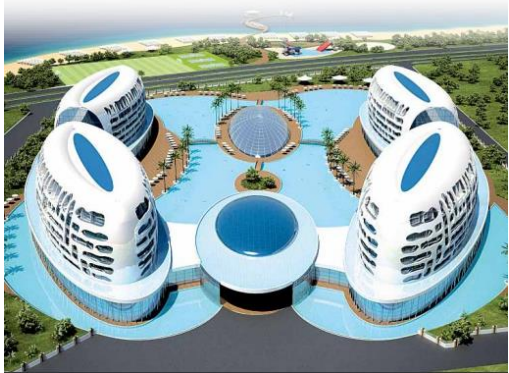

a

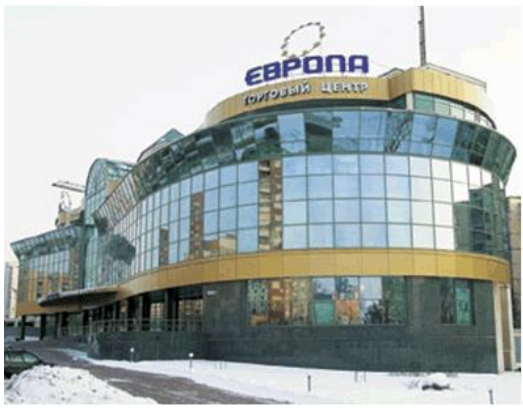

в)

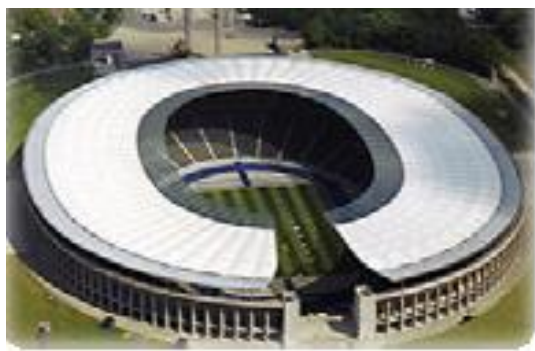

б)

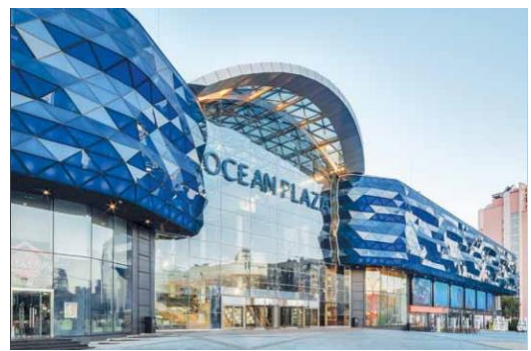

г)

Рис. 2. Будівлі з використанням металоконструкцій: а) - офісний центр, Анталія; б) - олімпійський стадіон в Мюнхені; в, г) - торгові центри Європа i Ocean Plaza, м. Київ

До переваг швидкомонтованих будівель із сталевим каркасом можна віднести $[6,7]$ :

- швидкість монтажу (зведення аналогічних будівель з бетону або цегли вимагає в 6-10 разів більше часу);

- економія на ціні (на 20-30\% дешевше будь-яких інших альтернативних методів будівництва);

- мала вага конструкцій дозволяє заощадити на фундаменті;

- будівлі із сендвіч-панелей можна зібрати та розібрати в будь-якому зручному місці;

- виконання будівельних робіт в будь-яку пору року;

- довговічність, сейсмостійкість, безпека та стійкість перед негативними погодними умовами;

- немає потреби в фасадних роботах та інше.

До недоліків швидкомонтованих будівель із сталевим каркасом можна віднести - недостатню корозійну стійкість і малу вогнестійкість. 
Швидкомонтовані будівлі бездоганно відповідають духу сучасної архітектури.

Металеві конструкції при експлуатації 3 плинністю часу можуть піддаватися впливу корозії, а тому при їх проектуванні необхідно дотримуватися таких вимог:

« - зниження ступеня агресивності впливів природних та виробничих середовищ за рахунок засобів екологічного захисту;

- визначення вимог безпеки до матеріалів та конструкцій при виборі варіантів первинного та вторинного захисту від корозії;

- впровадження існуючих корозійностійких матеріалів для забезпечення первинного захисту будівельних матеріалів, виробів i конструкцій;

- впровадження ефективних засобів та методів протикорозійного захисту з гарантованими показниками довговічності» [8].

При проектуванні сталевих конструкцій враховують вимоги стосовно забезпечення вогнестійкості [9]. Для об'єктів підвищеної надійності ще на стадії проєкту закладають використання спеціальних марок, що характеризуються теплотривкістю або жаростійкістю.

Передувало такому стану речей недосконала українська нормативна база, відсутність необхідних сортаментів вітчизняного виробництва, завищені вимоги до вогнезахисту конструкцій порівняно зі світовими стандартами, низька обізнаність і купівельна спроможність громадян та обмежені інвестиції в нові технології.

Однак після прийняття нового ДБН В.2.6-198:2014, де включено нові методики розрахунку конструкцій i ïx вузлів за європейськими стандартами [3], нові розробки програмного забезпечення (Tekla Structures, Building Informational Model, КОМПАC-3D V15, 3, 3D-моделювання Autodesk AutoCAD, ЛIPA-CAПР та ін.) посприяли оптимізації сталевого будівництва. 3 тих пір нарощення використання металевих конструкцій у сучасному будівництві зросло в 2 рази останні 3 роки поспіль.

\section{Висновки}

1. Використання металевих конструкцій при будівництві допомагає будувати в особливо тяжких кліматичних умовах і складному рельєфі місцевості. Здійснювати точкову забудову в населених районах.

2. Інвестиції у будівництво з використанням металевих конструкцій швидко окупаються і приносять економічне зростання не лише будівельній галузі, але й економіці країни в цілому.

3. Застосування металоконструкцій в промисловому, комерційному та житловому будівництві має значний потенціал.

4. Сталеві металоконструкції бездоганно відповідають духу сучасної архітектури. У комплексі з екологічністю і невисокою собівартістю це робить їх затребуваними і перспективними. 


\section{References}

1. Problematyka ta perspektyvy stalevoho budivnytstva $\mathrm{v}$ Ukraini. https://profbuild.in.ua/uk/intervyu-2/1680-problematika-ta-perspektivi-stalevogobudivnitstva-v-ukrajini.

2. Bilshe metalokonstruktsii u komertsiinomu budivnytstvi. http://steelbuildings.com.ua/izbrannye-stati/258-bilshe-metalokonstruktsij-ukomertsijnomu-budivnitstvi.

3. Stalevi konstruktsii. Normy proektuvannia. DBN V.2.6-198:2014. K.: Minrehion Ukrainy, 2014. 199 s.

4. Vykorystannia metalu $\mathrm{v}$ promyslovykh sporudakh. https://metinvestsmc.com/ua/articles/ispolzovanie-metalla-v-promyshlennykh-sooruzheniyakh/

5. Perevahy vykorystannia stalevykh konstruktsii $\mathrm{v}$ budivnytstvi. https://metinvest-smc.com/ua/articles/preimushchestva-ispolzovaniya-stalnykhkonstruktsiy-v-stroitelstve/

6. https// www.zdorovklimat.com.ua/067 373 6556/ Sendvich paneli Lviv Budivnytstvo z sendvich panelei.

7. http:// www.budivnytstvo.com.uа/будівництво 3/сендвіч панелей $067 \quad 509$ 3136. Budivnytstvo Z Sendvich Panelei - Vyhotovlennia Budivel pid ...

8. Zakhyst metalevykh konstruktsii vid korozii. Vymohy do proektuvannia. DSTU B V.2.6-193:2013. - K.: Minrehion Ukrainy, 2013.

9. Pozhezhna bezpeka obiektiv budivnytstva. Zahalni vymohy. DBN V1.17:2016. K.: Minrehion Ukrainy, 2017. 41 s.

\section{Список використаної літератури}

1. Проблематика та перспективи сталевого будівництва в Україні. https://profbuild.in.ua/uk/intervyu-2/1680-problematika-ta-perspektivi-stalevogobudivnitstva-v-ukrajini.

2. Більше металоконструкцій у комерційному будівництві. http://steelbuildings.com.ua/izbrannye-stati/258-bilshe-metalokonstruktsij-ukomertsijnomu-budivnitstvi

3. Сталеві конструкції. Норми проектування. ДБН В.2.6-198:2014. К.: Мінрегіон України, 2014. 199 с.

4. Використання металу в промислових спорудах. https://metinvestsmc.com/ua/articles/ispolzovanie-metalla-v-promyshlennykh-sooruzheniyakh/

5. Переваги використання сталевих конструкцій в будівництві. https://metinvest-smc.com/ua/articles/preimushchestva-ispolzovaniya-stalnykhkonstruktsiy-v-stroitelstve/

6. https// www.zdorovklimat.com.ua/ 067373 6556/ Сендвіч панелі Львів Будівництво з сендвіч панелей.

7. http:// www.budivnytstvo.com.ua/будівництво_3/сендвіч_панелей 067509 3136. Будівництво 3 Сендвіч Панелей - Виготовлення Будівель під...

8. Захист металевих конструкцій від корозії. Вимоги до проектування. ДСТУ Б В.2.6-193:2013. - К.: Мінрегіон України, 2013.

9. Пожежна безпека об'єктів будівництва. Загальні вимоги. ДБН В1.17:2016. К.: Мінрегіон України, 2017. 41 с. 